\title{
Parasitic Central Nervous System Infections in
}

\section{Immunocompromised Hosts: Malaria, Microsporidiosis, Leishmaniasis, and African Trypanosomiasis}

\author{
Melanie Walker ${ }^{1}$, James G. Kublin ${ }^{3}$, and Joseph R. Zunt ${ }^{1,2}$ \\ 1 Department of Neurology, University of Washington School of Medicine, Seattle, Washington \\ 2 Department of Medicine, Infectious Diseases Division, University of Washington School of Medicine, \\ Seattle, Washington
}

3 Fred Hutchinson Cancer Research Center, Seattle, Washington

\begin{abstract}
Immunosuppression associated with HIV infection or following transplantation increases susceptibility to central nervous system (CNS) infections. Because of increasing international travel, parasites that were previously limited to tropical regions pose an increasing infectious threat to populations at risk for acquiring opportunistic infection, especially people with HIV infection or individuals who have received a solid organ or bone marrow transplant. Although long-term immunosuppression caused by medications such as prednisone likely also increases the risk for acquiring infection and for developing CNS manifestations, little published information is available to support this hypothesis. In an earlier article published in Clinical Infectious Diseases, we described the neurologic manifestations of some of the more common parasitic CNS infections. This review will discuss the presentation, diagnosis, and treatment of the following additional parasitic CNS infections: malaria, microsporidiosis, leishmaniasis, and African trypanosomiasis.
\end{abstract}

As detailed in our previous article [1], the risk of acquiring fungal, viral, bacterial or parasitic infection is increased in patients receiving immunosuppressive therapy after transplantation and in people with advanced HIV infection. CNS infection occurs in 5\%-10\% of transplant recipients and up to $19 \%$ of patients with AIDS [2]. Patients with advanced HIV infection $\left(\mathrm{CD} 4+\right.$ cell count,$<200$ cells $\left./ \mathrm{mm}^{3}\right)$ and patients who require high levels of immunosuppression because of graft rejection or graft-versus-host disease are at greater risk than others of developing opportunistic CNS infections. Although parasitic CNS infection can occur in any host, some infections are more common among patients undergoing specific types of transplantation (table 1). The clinical and radiographic manifestations of parasitic CNS infection are often similar in immunocompromised and immunocompetent hosts, but certain infections may blunt or enhance these manifestations in immunosuppressed hosts [3,4]. Although neurologic symptoms vary somewhat by infecting parasite, they are mainly determined by the location(s) of the infection within the CNS (table 2).

Evaluation of the immunosuppressed host presenting with neurologic symptoms or signs of infection should be guided by (1) the degree of immunosuppression, type of transplant received,

Reprints or correspondence: Dr. Joseph R. Zunt, Harborview Medical Center, 325 9th Ave., Box 359775, Seattle, WA 98105 (E-mail: jzunt@u.washington.edu).

David R. Snydman, Section Editor

Potential conflicts of interest. All authors: no conflicts. 
or $\mathrm{CD} 4^{+}$cell count, (2) the length of time since transplantation and the type of immunosuppressive therapy received (for transplant recipients), (3) the results of serological testing for infections endemic to the host's country of origin or transit, (4) concomitant systemic symptoms (especially pulmonary and gastrointestinal), and (5) neuroimaging findings (table 2). Diagnostic testing should then be directed toward detecting the organism or antibody response to the parasite (table 3). Eosinophilia in CSF or blood samples may be absent during parasitic CNS infection, especially during long-term infection [5].

Treatment of a parasitic infection should be guided by the local availability of medications, because some medications are not available in certain countries (table 4). In addition, The Medical Letter publishes periodic treatment guidelines for parasitic infections [6]. Because many individuals who are infected with HIV or who have received a transplant require medications that may alter or be altered by the medications used for treatment of parasitic infection, a pharmacist or other source should be consulted to assist with assessment for potential drug-drug interactions.

\section{MALARIA}

Malaria is caused by an intracellular protozoan transmitted via the bite of an infected female Anopheles mosquito. In humans, malaria can be caused by any of 4 Plasmodium species: Plasmodium falciparum, Plasmodium ovale, Plasmodium vivax, or Plasmodium malariae. Although $P$. vivax is present in most areas of malaria endemicity, $P$. falciparum produces the highest mortality. The annual incidence of malaria is difficult to estimate, but recent estimates suggest that malaria causes 1.1-2.7 million deaths annually (predominantly among children living in sub-Saharan Africa) and that it infected $>500$ million people in 2002 [7-9]. The incidence of malaria is increasing because of a combination of drug and insecticide resistance, as well as because of social and environmental changes [10].

Malaria is not an opportunistic infection for HIV-infected people, but the effect of HIV infection on the natural history of malaria has not been completely defined. Although initial studies in areas where malaria and HIV infection are coendemic suggested no more than observed coexistence between these pathogens, subsequent studies detected not only an impact of HIV infection on the clinical course of malaria but also an impact of malaria on the clinical course of HIV infection [3,4,11,12]. For example, compared with people without HIV infection, HIV-infected people with malaria have a higher prevalence of fever, parasitemia, cerebral malaria, and severe or complicated malaria [5,13-18]. HIV-infected women with malaria are also more likely to become parasitemic and to have higher parasite density than are HIV-uninfected women [19,20]. Similar findings have been documented in nonpregnant women and in men, and the clinical severity of malaria worsens with advanced immunosuppression [21-23].

In a cross-sectional study of HIV-infected adults with acute falciparum malaria in Malawi, plasma HIV levels were higher for HIV-infected people with parasitemia than for HIV-infected people without parasitemia [24]. This study was followed by a prospective cohort study which found that HIV-infected people with malaria had significantly elevated HIV loads [25]. The increases were greatest for people with fever, a parasite density of $\geq 2000$ parasites $/ \mu \mathrm{L}$, and a $\mathrm{CD} 4^{+}$cell count of $>300$ cells $/ \mu \mathrm{l}$; for these patients, a mean log increase of 0.82 (95\% CI, $0.55-$ 1.10) was observed. Such an increase could theoretically accelerate disease progression or increase the risk of HIV transmission [26-28].

Malaria has been transmitted by infected donor organ and bone marrow, but the effect of immunocompromised conditions other than HIV infection on the natural history of malaria has not been defined [29,30]. Malaria has been manifest in people receiving corticosteroids and in 
African black-footed penguins receiving dexamethasone, but additional information regarding outcomes is not available [31-33].

The clinical presentation of malaria ranges from asymptomatic to severe and is largely dependent on host immune status and infecting Plasmodium species. The host immune status is determined by age, previous parasite exposure, and degree of endemicity of malaria in the environment. Children and pregnant women are at greater risk than others for developing severe or fatal disease. Typical symptoms in a host with no previous parasite exposure include fever, chills, headache, myalgias and arthralgias, diarrhea and vomiting, and other nonspecific signs and symptoms.

Cerebral malaria is a well-known complication of severe malaria and is defined as an unarousable state of unconsciousness, accompanied by the presence of asexual parasitemia (most often due to $P$. falciparum). Cerebral malaria is usually preceded by several days of nonspecific feverish symptoms, but it may occur within $24 \mathrm{~h}$ after development of the first symptoms. Episodic fevers may be accompanied by diaphoresis, headache, malaise, arthralgias, myalgias, nausea, or dizziness. Generalized seizures occur in $20 \%-50 \%$ of patients, most often in people infected with $P$. falciparum [34]. In children, seizures are typically recurrent and often focal. Coma may develop subacutely or precipitously after a generalized seizure and typically lasts 1-3 days. Hypoglycemia and prolonged postictal unresponsiveness are common during malaria and should be excluded as causes of a comatose state. Signs of increased intracranial pressure, such as papilledema and meningismus, are uncommon [35]. Cranial nerve dysfunction (such as horizontal or vertical nystagmus, ocular bobbing, or sixth nerve palsy) and decerebrate posturing are occasionally present [36-38]. In addition to the acute-phase manifestations of cerebral malaria, others have described a neurologic syndrome that may develop weeks or months after resolution of the acute phase of the infection. This syndrome, known as postmalaria neurological syndrome, by definition occurs in the absence of parasitemia and most frequently includes seizures, cognitive dysfunction, and psychiatric manifestations [39,40]. Although severe malaria, including cerebral malaria, has been reported following transplantation and in HIV-infected people, it is not clear that the incidence of cerebral malaria is elevated in either population. In early studies, rates of cerebral malaria among people with and people without HIV infection were reported to be both elevated and decreased for both groups, depending on the study [41,42]. A subsequent larger study involving 310 patients with malaria recently found that severe malaria was more common among HIVinfected people than among others (47\% vs. 30\%) and that severe malaria was more often associated with coma for HIV-infected people than for others (16\% vs. 8\%) [17].

The exact pathogenic mechanism of cerebral malaria has not been well established, but an autopsy study of fatal cases of cerebral malaria in children suggests that cerebral malaria is likely to be caused by the sequestration of RBCs containing Plasmodium trophozoites and meronts within cerebral capillaries and venules [43]. Petechial hemorrhages and endothelial activation are present in brains of people who die with cerebral malaria [44]. Impairment of the blood-brain barrier, as well as axonal injury and impairment of axonal transport, have been implicated as possible causes of CNS dysfunction $[45,46]$.

The diagnosis of malaria requires an index of suspicion based on the patient's exposure history and clinical presentation. Giemsa staining of thick and thin blood smears can detect parasitemia and identify malarial species. Serological tests (ParaSight-F and Immunochromotographic Malaria P. falciparum test) are available, but false-positive test results are common [47]. Confirmation of cerebral malaria requires an unarousable state of unconsciousness, accompanied by the presence of asexual parasitemia (most often P. falciparum) and exclusion of other causes of an unconscious state, such as hypoglycemia, postictal sedation, or other CNS infection [48]. Brain CT may demonstrate cerebral edema during cerebral malaria, as evidenced 
by effacement of the cortical sulci and small or slit-like ventricles, and when this finding is accompanied by hypoattenuation of the basal ganglia or cerebellum, it portends poor prognosis $[49,50]$. MRI of the brain for patients with cerebral malaria has revealed diffuse swelling with or without edema, as well as multifocal cortical or subcortical lesions that may be enhanced after gadolinium administration [40,51,52]. Imaging analysis of a patient with acute cerebral malaria demonstrated multiple areas of high signal intensity on diffusion-weighted imaging with decreased signal on apparent diffusion coefficient maps, consistent with stroke [53]. Adnormal imaging findings can resolve if the patient recovers. Transtentorial herniation is a common finding on CT or MRI in fatal cases of cerebral malaria. MRI of patients with postmalaria neurologic syndrome, which is similar to acute demyelinating encephalomyelitis, may reveal enhancing, multifocal white matter abnormalities in the brain, brainstem, and posterior fossa that improve as symptoms resolve [40].

Choice of treatment should be guided by the Plasmodium species prevalent in the region where infection was acquired and the severity of malaria, and treatment should be initiated immediately after diagnosis is confirmed or when malaria is highly suspected. Chloroquineresistant P. falciparum is present in Southeast Asia, the Amazon region of South America, and certain areas of sub-Saharan Africa. In these areas, quinine with doxycycline, mefloquine, or newer antimalarial drugs (e.g., artemisinian derivatives) should be used [54]. For the traveler with suspected cerebral malaria due to chloroquine-resistant Plasmodium or Plasmodium with unknown resistance, initial treatment should include intravenous quinidine. The availability of drugs and the parasite burden also influence treatment strategy, as does age and reproductive status. Because of the complicated nature of treating malaria, local treatment guidelines and The Medical Letter should be consulted [6,55]. Steroids should not be administered to patients with cerebral malaria, because they have been associated with worse outcome $[48,56]$. In addition, although anticonvulsants are indicated for patients with cerebral malaria who develop seizures, routine prophylactic use of anticonvulsants may be associated with worse outcome $[57,58]$.

Poor prognosis is associated with longer duration of seizures, presence of retinal hemorrhages, coma, presence of hypoattenuation on CT images of the brain, hypoglycemia, and anemia $[35,59]$. Neurologic deficits may resolve quickly, slowly, or not at all: ataxia usually resolves rapidly, whereas hemiparesis or cortical blindness usually requires months to resolve. Children who develop spastic quadriparesis or vegetative state usually die. Residual neurologic sequelae occur in $\sim 10 \%$ of immunocompetent people and may include epilepsy and cognitive, behavioral, and language deficits, as well as hemiparesis, blindness, and ataxia $[58,60]$. The effect of immunosuppression on the incidence of long-term neurologic sequelae is not known.

\section{MICROSPORIDIOSIS}

Microsporidia are single-celled, obligate intracellular parasites under consideration for reclassification from protozoa to fungi [61]. More than 20 genera of microsporidium are pathogenic in mammals, with Encephalitozoon species affecting immunosuppressed populations more commonly than other species [62]. Three species of Encephalitozoon are known to cause disseminated disease in humans: Encephalitozoon intestinalis (also known as Septata intestinalis), Encephalitozoon hellem, and Encephalitozoon cuniculi [63]. Several other species have caused disseminated disease, including Trachipleistophora species (Trachipleistophora hominis and Trachipleistophora anthropopthera), Pleistorphora species (Pleistorphora ronneafiei and others), and Brachiola species (Brachiola vesicularum and Brachiola algerae). Of these, the Trachiplesitophora species have been associated with encephalitis and death. In humans, microsporidium can be transmitted via contaminated water or air droplets and via the fecal-oral route [64,65]. Sexual transmission of Encephalitozoon species may also occur [66]. Microsporidia possess a unique mechanism of infection: these 
parasites produce resilient spores with a polar apparatus capable of piercing a host cell and injecting infectious sporoplasm into the cytoplasm [67].

For HIV-infected people, increased rates of infection are associated with $\mathrm{CD} 4^{+}$counts of $<100$ cells $/ \mathrm{mm}^{3}$ but are not associated with higher viral load [68]. Disseminated infection can occur when $\mathrm{CD}^{+}$counts decrease to $<50$ cells $/ \mathrm{mm}^{3}[69,70]$. Microsporidiasis has been reported following transplantation, but most cases are detected postmortem [71]. Disseminated infection with CNS involvement has been reported following kidney, pancreas, and bone marrow transplantation [71-74].

Primary infection usually begins in the intestines, lungs, or, possibly, bladder and may be asymptomatic [63]. Most microsporidium infections in immunocompetent hosts are asymptomatic, but rare cases of CNS involvement presenting with seizures have been reported $[75,76]$. The most common clinical manifestation of infection among HIV-infected people is diarrhea, and CNS infection occurs only during disseminated infection, often accompanied by microsporidial sinusitis or keratoconjunctivitis [77]. Although CNS symptoms are dependent on lesion location, seizures are a common manifestation [74].

Diagnosis of microsporidiasis is most often made by detection of organisms in body fluids or tissue biopsy specimens $[78,79]$. Electron microscopy or light microscopy can be used to speciate microsporidium, but electron microscopy is more successful than light microscopy [80]. Although shedding of microsporidia can be detected in urinary sediment up to 6 months before onset of symptoms, diagnosis is difficult during early infection, and collection of a 24$\mathrm{h}$ urine sample increases the likelihood of detecting the organisms [81]. PCR of tissue biopsy samples is highly sensitive but is not widely available [82]. During CNS infection, spores are often present in peripheral blood [83,84]. CSF examination may demonstrate a neutrophilic pleocytosis and occasionally organisms $[65,85]$. Serological testing may not be reliable in late stages of HIV infection, because antibody levels are often decreased and difficult to detect [84]. Brain imaging usually reveals multifocal contrast-enhancing lesions in gray or white matter, and meningeal enhancement has been reported in a transplant recipient with CNS infection $[65,74,86,87]$. Biopsy of CNS lesions typically reveals necrosis and microsporidia spores [88].

Albendazole is effective for treatment of disseminated infection, but improvement may be transient [89]. For HIV-infected people, HAART provides the greatest chance for remission if the $\mathrm{CD}^{+}$count increases to $>100$ cells $/ \mathrm{mm}^{3}$; people without an increase often develop a fatal course $[68,90]$. Other medications have not been successful for disseminated infection.

\section{LEISHMANIASIS}

Leishmaniasis is an obligate intracellular protozoan infection transmitted by the bite of a female sand fly [2]. In injection drug users, syringe sharing is another potential route of transmission, because Leishmania parasites have been detected in used syringes [91]. Leishmaniasis is endemic in 88 countries, and nearly 2 million people become infected each year [92]. More than 20 Leishmania species can infect humans, with most infections due to Leishmania donovani group, specifically Leishmania infantatum [93]. In countries where leishmaniasis is endemic, such as India, Nepal, Bangladesh, and Sudan, visceral disease is more commonly encountered in immunocompetent than in immunosuppressed hosts, but disseminated infection is more common in immunosuppressed hosts [94-96]. Among HIV-infected people, higher HIV load is associated with higher prevalence of Leishmania coinfection, and lower CD4 ${ }^{+}$cell count is associated with visceral and disseminated forms of leishmaniasis [94,95]. Visceral disease is more common among people with $\mathrm{CD}^{+}$cell counts of $<300$ cells $/ \mathrm{mm}^{3}$, but disseminated infection usually does not occur until the cell count is $<50$ cells $/ \mathrm{mm}^{3}$ [97]. Visceral leishmaniasis is the fourth most common AIDS-related infection in southern Spain 
[97]. HAART decreases the incidence of visceral infection [98,99]. Leishmaniasis, including visceral disease, has also been reported in patients with immunosuppression following transplantation, in people receiving chronic corticosteroid treatment, and in people with blood dyscrasias [100-106].

Leishmaniasis can produce cutaneous, mucocutaneous, gastrointestinal, or visceral manifestations, and some Leishmania species have a predilection for producing one or more of these manifestations [107]. The host defense against Leishmania infection is an important determinant of the clinical presentation. Primary infection is usually limited to cutaneous involvement. HIV infection is associated with decreased response to treatment and recurrent infection [105,108]. Although HIV-infected people with visceral leishmaniasis often present with the classical triad of fever, hepatosplenomegaly, and pancytopenia, some present with only fever [109]. In HIV-infected people, symptomatic leishmaniasis may represent reactivation of latent infection rather than primary infection; consistent with this theory, some people develop symptoms years after leaving areas of endemicity [110]. Regardless of host immune status, the most common neurologic manifestation of leishmaniasis is peripheral neuropathy; CNS manifestations are uncommon, regardless of host immune status, but have been reported in immunosuppressed people, usually in conjunction with disseminated infection [111,112]. CNS involvement is believed to occur via extension of contiguous infection, most often from the paranasal sinuses; cranial nerve dysfunction and meningitis have been reported [113-116]. Optic nerve involvement has been reported following extension of conjunctival and sinus infection to the orbital apex, with invasion and erosion of adjacent bony structures [117]. Aside from painful peripheral neuropathies, an ascending demyelinating disease similar to Guillain-Barré syndrome has been reported, but it was largely localized to the peripheral nervous system $[118,119]$.

Diagnosis of leishmaniasis may be made by direct identification of amastigotes in biopsy tissue, serological testing, or PCR. Although serological testing is both sensitive and specific in immunocompetent hosts, in HIV-infected hosts, antibody detection for visceral disease by ELISA or immunofluorescence assay has a sensitivity of only $40 \%-50 \%[120,121]$. Up to $60 \%$ of HIV-infected people with leishmaniasis have amastigotes in serum samples, and amastigotes have been detected in CSF [94,122]. PCR may have a much higher yield, with some studies reporting $100 \%$ sensitivity $[123,124]$. Culture remains the gold standard for speciation, but PCR can be used for speciation in some laboratories. There are no neuroimaging findings specific to CNS leishmaniasis, but CT of the head may be useful for patients with ocular or sinus disease and potential bony invasion [117].

The treatments of choice for visceral leishmaniasis are miltefosine, sodium stibogluconate, or amphotericin B lipid complex, but miltefosine is not available in the United States. Many treatments can produce severe side effects, and most are parenteral [125]. Amphotericin B lipid complex has been used as first-line therapy for HIV-infected people [126]. Up to 30\% of HIVinfected people with leishmaniasis experience relapse within 6 months after treatment, regardless of the treatment used; therefore, chronic suppressive therapy is recommended $[127,128]$. In HIV-infected people, treatment failure and resistance to standard medications are common, so combination therapy is often necessary [129]. Concomitant administration of HAART decreases the incidence of symptomatic visceral leishmaniasis [97].

\section{AFRICAN TRYPANOSOMIASIS}

Human African trypanosomiasis (HAT) can be caused by Trypanosoma brucei gambiense (in western and central Africa) or T. brucei rhodesiense (in eastern Africa) and is contracted from the bite of the tsetse fly (genus Glossina) [130]. Although the 2 T. brucei subspecies causing HAT are morphologically similar and produce clinically similar CNS symptoms during the 
second stage of infection, T. brucei rhodesiense progresses from first stage to second stage over weeks rather than months or years [131]. Coinfection with HIV likely modifies the response to treatment but appears to have little if any effect on the clinical manifestations of HAT [132-134]. There are no reported cases of HAT in patients who have received organ or bone marrow transplants, perhaps because of limited disease surveillance and the infrequency of transplantation in these regions of Africa [130]. Although few cases of HAT have been reported outside of tropical Africa, with increasing migration and international travel, HAT is being observed more frequently in the Western Hemisphere [135].

The clinical manifestations of HAT are divided into 2 stages. First-stage symptoms develop 1-3 weeks after the tsetse fly bite and are typically mild. Nonspecific symptoms, such as fever, headache, and malaise, are common, and patients may recall a chancre at the site of inoculation [136]. The second stage of infection is when CNS manifestations begin. T. brucei rhodesiense tends to be more aggressive than $T$. brucei gambiense and progresses to the second stage of disease within weeks to months [137]. Initial symptoms may include abnormal gait or speech, mental status changes, and abnormal movements [138]. Sleep disturbance is a classic feature of infection and is usually accompanied by lassitude and distractibility. The normal sleep-wake cycle is reversed, resulting in daytime somnolence and nocturnal insomnia [139]. Progression to late-stage infection may be rapid if due to $T$. brucei rhodesiense or progress over months if due to T. brucei gambiense, and it can produce a broad spectrum of neurologic symptoms, including sensori-motor abnormalities, seizures, or coma [137]. The clinical manifestation of infection does not appear to vary by host immune status [132-134].

Diagnosis of HAT is most often made by detection of trypansome-specific antibodies with the card agglutination test for trypanosomiasis. Positive card agglutination test results always requires parasitological confirmation, and CNS infection is confirmed by identification of trypanosomes and elevated WBC count in CSF samples [140]. Although detection of antitrypanosomal IgM in CSF and pleocytosis confirms CNS involvement, some investigators propose increasing the CSF WBC count threshold from $>5$ cells $/ \mu \mathrm{L}$ to $>20$ cells $/ \mu \mathrm{L}$ to improve specificity for CNS involvement [141]. Neuroimaging findings with CT are often normal, but MRI may reveal hypointensity in the basal ganglia [142].

Treatment with pentamidine and/or suramin is successful for early infection but not when CNS involvement is present [143]. Once trypanosomes have entered the CNS, melarsoprol is the only potentially effective treatment for both infections [144]. Eflornithine is effective for CNS infection with T. b. gambiense, but it is not available in the United States. No other medication effectively crosses the blood-brain barrier without producing significant toxicity [131]. With treatment, the mortality rate is $2 \%-7 \%$; untreated, the infection is uniformly fatal [145]. Compared with immunocompetent people with HAT, HIV-infected people appear to have higher risk for treatment failure and worse outcome of both HAT and HIV infection [146, 147]. Treatment with suramin may prevent HIV from penetrating CD4 ${ }^{+}$cells and inhibit reverse-transcriptase activity [143,148].

\section{CONCLUSIONS}

With the exception of cerebral malaria, most parasitic infections of the CNS are uncommon. During some years, outbreaks of endemic infections, such as HAT, may alter the expected epidemiologic characteristics of CNS infections. Although information regarding the effect of immunosuppression on the clinical manifestations and treatment efficacy of parasitic infection is sparse, available information suggests that both HIV infection and transplant-associated immunosuppression lessen the sensitivity of serological testing and increase the risk of disseminated infection and CNS involvement. Clinical manifestations of infection are most often similar to those observed in immunocompetent hosts. Involvement of the CNS typically 
portends a poor prognosis. In HIV-infected people, parasitic coinfection usually adversely affects the natural history of HIV infection, but treatment of HIV infection may provide improvement of both conditions.

\section{Acknowledgements}

Financial support. National Institutes of Health Fogarty International Center (R21 NS48838 to J.R.Z.) and University of Washington Center for AIDS Research (AI27757).

\section{References}

1. Walker M, Zunt JR. Parasitic central nervous system infections in immunocompromised hosts. Clin Infect Dis 2005;40:1005-15. [PubMed: 15824993]

2. Harms G, Feldmeier H. HIV infection and tropical parasitic diseases: deleterious interactions in both directions? Trop Med Int Health 2002;7:479-88. [PubMed: 12031069]

3. Greenberg AE, Nsa W, Ryder RW, et al. Plasmodium falciparum malaria and perinatally acquired human immunodeficiency virus type 1 infection in Kinshasa, Zaire: a prospective, longitudinal cohort study of 587 children. N Engl J Med 1991;325:105-9. [PubMed: 2052043]

4. Colebunders R, Bahwe Y, Nekwei W, et al. Incidence of malaria and efficacy of oral quinine in patients recently infected with human immunodeficiency virus in Kinshasa, Zaire. J Infect 1990;21:167-73. [PubMed: 2230175]

5. Atzori C, Bruno A, Chichino G, et al. HIV-1 and parasitic infections in rural Tanzania. Ann Trop Med Parasitol 1993;87:585-93. [PubMed: 8122920]

6. The medical letter on drugs and therapeutics. New Rochelle, NY: Medical Letter; 2004. Drugs for parasitic infections; p. 1-12.

7. Bryce J, Boschi-Pinto C, Shibuya K, Black RE. World Health Organization estimates of the causes of death in children. Lancet 2005;365:1147-52. [PubMed: 15794969]

8. Snow RW, Guerra CA, Noor AM, Myint HY, Hay SI. The global distribution of clinical episodes of Plasmodium falciparum malaria. Nature 2005;434:214-7. [PubMed: 15759000]

9. Wernsdorfer G, Wernsdorfer WH. Malaria at the turn from the 2nd to the 3rd millenium. Wien Klin Wochenschr 2003;115(Suppl 3):2-9. [PubMed: 15508773]

10. Greenwood B, Mutabingwa T. Malaria in 2002. Nature 2002;415:670-2. [PubMed: 11832954]

11. Muller O, Moser R. The clinical and parasitological presentation of Plasmodium falciparum malaria in Uganda is unaffected by HIV-1 infection. Trans R Soc Trop Med Hyg 1990;84:336-8. [PubMed: 2260160]

12. Nguyen-Dinh P, Greenberg AE, Mann JM, et al. Absence of association between Plasmodium falciparum malaria and human immunodeficiency virus infection in children in Kinshasa, Zaire. Bull World Health Organ 1987;65:607-13. [PubMed: 3322600]

13. Steketee RW, Wirima JJ, Bloland PB, et al. Impairment of a pregnant woman's acquired ability to limit Plasmodium falciparum by infection with human immunodeficiency virus type-1. Am J Trop Med Hyg 1996;55:42-9. [PubMed: 8702036]

14. Chirenda J, Siziya S, Tshimanga M. Association of HIV infection with the development of severe and complicated malaria cases at a rural hospital in Zimbabwe. Cent Afr J Med 2000;46:5-9. [PubMed: 14674199]

15. Simooya OO, Mwendapole RM, Siziya S, Fleming AF. Relation between falciparum malaria and HIV seropositivity in Ndola, Zambia. BMJ 1988;297:30-1. [PubMed: 3044486]

16. Leaver RJ, Haile Z, Watters DA. HIV and cerebral malaria. Trans R Soc Trop Med Hyg 1990;84:201. [PubMed: 2389309]

17. Grimwade K, French N, Mbatha DD, Zungu DD, Dedicoat M, Gilks CF. HIV infection as a cofactor for severe falciparum malaria in adults living in a region of unstable malaria transmission in South Africa. AIDS 2004;18:547-54. [PubMed: 15090809]

18. Grimwade K, French N, Mbatha DD, Zungu DD, Dedicoat M, Gilks CF. Childhood malaria in a region of unstable transmission and high human immunodeficiency virus prevalence. Pediatr Infect Dis J 2003;22:1057-63. [PubMed: 14688565] 
19. van Eijk AM, Ayisi JG, ter Kuile FO, et al. Human immunodeficiency virus seropositivity and malaria as risk factors for third-trimester anemia in asymptomatic pregnant women in western Kenya. Am J Trop Med Hyg 2001;65:623-30. [PubMed: 11716125]

20. Verhoeff FH, Brabin BJ, Chimsuku L, Kazembe P, Broadhead RL. Malaria in pregnancy and its consequences for the infant in rural Malawi. Ann Trop Med Parasitol 1999;93(Suppl 1):S25-33. [PubMed: 10715686]

21. Whitworth J, Morgan D, Quigley M, et al. Effect of HIV-1 and increasing immunosuppression on malaria parasitaemia and clinical episodes in adults in rural Uganda: a cohort study. Lancet 2000;356:1051-6. [PubMed: 11009139]

22. Francesconi P, Fabiani M, Dente MG, et al. HIV, malaria parasites, and acute febrile episodes in Ugandan adults: a case-control study. AIDS 2001;15:2445-50. [PubMed: 11740196]

23. French N, Nakiyingi J, Lugada E, Watera C, Whitworth JA, Gilks CF. Increasing rates of malarial fever with deteriorating immune status in HIV-1-infected Ugandan adults. AIDS 2001;15:899-906. [PubMed: 11399962]

24. Hoffman IF, Jere CS, Taylor TE, et al. The effect of Plasmodium falciparum malaria on HIV-1 RNA blood plasma concentration. AIDS 1999;13:487-94. [PubMed: 10197377]

25. Kublin JG, Patnaik P, Jere CS, et al. Effect of Plasmodium falciparum malaria on concentration of HIV-1 RNA in the blood of adults in rural Malawi: a prospective cohort study. Lancet 2005;365:23340. [PubMed: 15652606]

26. Bentwich Z, Kalinkovich A, Weisman Z. Immune activation is a dominant factor in the pathogenesis of African AIDS. Immunol Today 1995;16:187-91. [PubMed: 7734046]

27. Quinn TC, Wawer MJ, Sewankambo N, et al. Viral load and heterosexual transmission of human immunodeficiency virus type 1. Rakai Project Study Group. N Engl J Med 2000;342:921-9. [PubMed: 10738050]

28. Whalen C, Horsburgh CR, Hom D, Lahart C, Simberkoff M, Ellner J. Accelerated course of human immunodeficiency virus infection after tuberculosis. Am J Respir Crit Care Med 1995;151:129-35. [PubMed: 7812542]

29. Salutari $\mathrm{P}$, Sica $\mathrm{S}$, Chiusolo $\mathrm{P}$, et al. Plasmodium vivax malaria after autologous bone marrow transplantation: an unusual complication. Bone Marrow Transplant 1996;18:805-6. [PubMed: 8899200]

30. Chiche L, Lesage A, Duhamel C, et al. Posttransplant malaria: first case of transmission of Plasmodium falciparum from a white multiorgan donor to four recipients. Transplantation 2003;75:166-8. [PubMed: 12544892]

31. Chadee DD, Tilluckdharry CC, Maharaj P, Sinanan C. Reactivation of Plasmodium malariae infection in a Trinidadian man after neurosurgery. N Engl J Med 2000;342:1924. [PubMed: 10877649]

32. Cranfield MR, Graczyk TK, Beall FB, Ialeggio DM, Shaw ML, Skjoldager ML. Subclinical avian malaria infections in African black-footed penguins (Spheniscus demersus) and induction of parasite recrudescence. J Wildl Dis 1994;30:372-6. [PubMed: 7933280]

33. Ng CK, Mak AY, Au TS, Au TC, Lai ST, Lai JY. Plasmodium infection unmasked by corticosteroid therapy. Hong Kong Med J 1997;3:328-30. [PubMed: 11847382]

34. White NJ, Looareesuwan S, Phillips IA, et al. Single dose phenobarbitone prevents convulsions in cerebral malaria. Lancet 1988;2:64-6. [PubMed: 2898696]

35. Newton CRJC, Hien TT, White NJ. Cerebral malaria. J Neurol Neurosurg Psychiatry 2000;69:43341. [PubMed: 10990500]

36. Warrell DA. Cerebral malaria: clinical features, pathophysiology and treatment. Ann Trop Med Parasitol 1997;91:875-84. [PubMed: 9625945]

37. Newton CR, Hien TT, White N. Cerebral malaria. J Neurol Neurosurg Psychiatry 2000;69:433-41. [PubMed: 10990500]

38. Newton CR, Crawley J, Sowumni A, et al. Intracranial hypertension in Africans with cerebral malaria. Arch Dis Child 1997;76:219-26. [PubMed: 9135262]

39. Nguyen TH, Day NP, Ly VC, et al. Post-malaria neurological syndrome. Lancet 1996;348:917-21. [PubMed: 8843810] 
40. Mohsen AH, McKendrick MW, Schmid ML, Green ST, Hadjivassiliou M, Romanowski C. Postmalaria neurological syndrome: a case of acute disseminated encephalomyelitis? J Neurol Neurosurg Psychiatry 2000;68:388-9. [PubMed: 10787306]

41. Goodgame RW. AIDS in Uganda: clinical and social features. N Engl J Med 1990;323:383-9. [PubMed: 2196463]

42. AIDS in Africa. N Engl J Med 1991;324:847-8. [PubMed: 1997859]

43. MacPherson GG, Warrell MJ, White NJ, Looareesuwan S, Warrell DA. Human cerebral malaria: a quantitative ultrastructural analysis of parasitized erythrocyte sequestration. Am J Pathol 1985;119:385-401. [PubMed: 3893148]

44. Turner G. Cerebral malaria. Brain Pathol 1997;7:569-82. [PubMed: 9034566]

45. Medana IM, Day NP, Hien TT, et al. Axonal injury in cerebral malaria. Am J Pathol 2002;160:65566. [PubMed: 11839586]

46. Gitau EN, Newton CR. Review article: blood-brain barrier in falciparum malaria. Trop Med Int Health 2005;10:285-92. [PubMed: 15730513]

47. Kodisinghe HM, Perera KL, Premawansa S, Naotunne T, Wickramasinghe AR, Mendis KN. The ParaSight-F dipstick test as a routine diagnostic tool for malaria in Sri Lanka. Trans R Soc Trop Med Hyg 1997;91:398-402. [PubMed: 9373632]

48. Warrell DA, Looareesuwan S, Warrell MJ, et al. Dexamethasone proves deleterious in cerebral malaria: a double-blind trial in 100 comatose patients. N Engl J Med 1982;306:313-9. [PubMed: 7033788]

49. Looareesuwan S, Warrell DA, White NJ, et al. Do patients with cerebral malaria have cerebral oedema? A computed tomography study. Lancet 1983;1:434-7. [PubMed: 6131165]

50. Patankar TF, Karnad DR, Shetty PG, Desai AP, Prasad SR. Adult cerebral malaria: prognostic importance of imaging findings and correlation with postmortem findings. Radiology 2002;224:8116. [PubMed: 12202719]

51. Looareesuwan S, Wilairatana $P$, Krishna S, et al. Magnetic resonance imaging of the brain in patients with cerebral malaria. Clin Infect Dis 1995;21:300-9. [PubMed: 8562735]

52. Cordoliani YS, Sarrazin JL, Felten D, Caumes E, Leveque C, Fisch A. MR of cerebral malaria. AJNR Am J Neuroradiol 1998;19:871-4. [PubMed: 9613502]

53. Sakai O, Barest GD. Diffusion-weighted imaging of cerebral malaria. J Neuroimaging 2005;15:27880. [PubMed: 15951412]

54. Tran TH, Day NP, Nguyen HP, et al. A controlled trial of artemether or quinine in Vietnamese adults with severe falciparum malaria. N Engl J Med 1996;335:76-83. [PubMed: 8649493]

55. Management of severe malaria: a practical handbook. Geneva: World Health Organization; 2005.

56. Hoffman SL, Rustama D, Punjabi NH, et al. High-dose dexamethasone in quinine-treated patients with cerebral malaria: a double-blind, placebo-controlled, randomised controlled trial. Lancet 1988;158:325-31.

57. Meremikwu M, Marson AG. Routine anticonvulsants for treating cerebral malaria. Cochrane Database Syst Rev 2002:CD002152. [PubMed: 12076440]

58. Molyneux ME, Taylor TE, Wirima JJ, Borgstein A. Clinical features and prognostic indicators in paediatric cerebral malaria: a study of 131 comatose Malawian children. Q J Med 1989;71:441-59. [PubMed: 2690177]

59. Patankar TF, Karnad DR, Shetty PG, Desai AP, Prasad SR. Adult cerebral malaria: prognostic importance of imaging findings and correlation with postmortem findings. Radiology 2002;224:8116. [PubMed: 12202719]

60. Holding PA, Stevenson J, Peshu N, et al. Cognitive sequelae of severe malaria with impaired consciousness. Trans R Soc Trop Med Hyg 1999;93:529-34. [PubMed: 10696414]

61. Didier ES, Stovall ME, Green LC, Brindley PJ, Sestak K, Didier PJ. Epidemiology of microsporidiosis: sources and modes of transmission. Vet Parasitol 2004;126:145-66. [PubMed: 15567583]

62. Weiss LM. Microsporidia: emerging pathogenic protists. Acta Trop 2001;78:89-102. [PubMed: 11230819] 
63. Franzen C, Muller A. Microsporidiosis: human diseases and diagnosis. Microbes Infect 2001;3:389400. [PubMed: 11369276]

64. Hutin YJ, Sombardier MN, Liguory O, et al. Risk factors for intestinal microsporidiosis in patients with human immunodeficiency virus infection: a case-control study. J Infect Dis 1998;178:904-7. [PubMed: 9728570]

65. Weber R, Deplazes P, Flepp M, et al. Cerebral microsporidiosis due to Encephalitozoon cuniculi in a patient with human immunodeficiency virus infection. N Engl J Med 1997;336:474-8. [PubMed: 9017940]

66. Schwartz DA, Visvesvara G, Weber R, Bryan RT. Male genital tract microsporidiosis and AIDS: prostatic abscess due to Encephalitozoon hellem. J Eukaryot Microbiol 1994;41:61S. [PubMed: 7804260]

67. Bigliardi E, Sacchi L. Cell biology and invasion of the microsporidia. Microbes Infect 2001;3:3739. [PubMed: 11369274]

68. Maggi P, Larocca AM, Quarto M, et al. Effect of antiretroviral therapy on cryptosporidiosis and microsporidiosis in patients infected with human immunodeficiency virus type 1. Eur J Clin Microbiol Infect Dis 2000;19:213-7. [PubMed: 10795595]

69. Oldfield EC 3rd. Evaluation of chronic diarrhea in patients with human immunodeficiency virus infection. Rev Gastroenterol Disord 2002;2:176-88. [PubMed: 12481169]

70. Chu P, West AB. Encephalitozoon (Septata) intestinalis: cytologic, histologic, and electron microscopic features of a systemic intestinal pathogen. Am J Clin Pathol 1996;106:606-14. [PubMed: 8929470]

71. Carlson JR, Li L, Helton CL, et al. Disseminated microsporidiosis in a pancreas/kidney transplant recipient. Arch Pathol Lab Med 2004;128:e41-3. [PubMed: 14987135]

72. Rabodonirina M, Cotte L, Radenne S, Besada E, Trepo C. Microsporidiosis and transplantation: a retrospective study of 23 cases. J Eukaryot Microbiol 2003;50(Suppl):583. [PubMed: 14736172]

73. Teachey DT, Russo P, Orenstein JM, Didier ES, Bowers C, Bunin N. Pulmonary infection with microsporidia after allogeneic bone marrow transplantation. Bone Marrow Transplant 2004;33:299_ 302. [PubMed: 14628080]

74. Mohindra AR, Lee MW, Visvesvara G, et al. Disseminated microsporidiosis in a renal transplant recipient. Transpl Infect Dis 2002;4:102-7. [PubMed: 12220248]

75. Bergquist NR, Stintzing G, Smedman L, Waller T, Andersson T. Diagnosis of encephalitozoonosis in man by serological tests. Br Med J (Clin Res Ed) 1984;288:902.

76. Matsubayashi H, Koike T, Mikata I, Takei H, Hagiwara S. A case of Encephalitozoon-like body infection in man. AMA Arch Pathol 1959;67:181-7. [PubMed: 13616827]

77. Yachnis AT, Berg J, Martinez-Salazar A, et al. Disseminated microsporidiosis especially infecting the brain, heart, and kidneys: report of a newly recognized pansporoblastic species in two symptomatic AIDS patients. Am J Clin Pathol 1996;106:535-43. [PubMed: 8853044]

78. Franzen C, Muller A, Hartmann P, Salzberger B. Quantitation of microsporidia in cultured cells by flow cytometry. Cytometry A 2004;60A:107-14. [PubMed: 15229863]

79. Weiss LM, Vossbrinck CR. Microsporidiosis: molecular and diagnostic aspects. Adv Parasitol 1998;40:351-95. [PubMed: 9554079]

80. Bryan RT, Weber R. Microsporidia: emerging pathogens in immunodeficient persons. Arch Pathol Lab Med 1993;117:1243-5. [PubMed: 8250696]

81. Weber R, Bryan RT, Schwartz DA, Owen RL. Human microsporidial infections. Clin Microbiol Rev 1994;7:426-61. [PubMed: 7834600]

82. Reetz J, Wiedemann M, Aue A, et al. Disseminated lethal Encephalitozoon cuniculi (genotype III) infections in cotton-top tamarins (Oedipomidas oedipus): a case report. Parasitol Int 2004;53:29-34. [PubMed: 14984833]

83. Menotti J, Cassinat B, Sarfati C, Liguory O, Derouin F, Molina JM. Development of a real-time PCR assay for quantitative detection of Encephalitozoon intestinalis DNA. J Clin Microbiol 2003;41:1410-3. [PubMed: 12682122]

84. Cheney SA, Lafranchi-Tristem NJ, Canning EU. Serological differentiation of microsporidia with special reference to Trachipleistophora hominis. Parasite 2001;8:91-7. [PubMed: 11474986] 
85. Franzen C. Microsporidia: how can they invade other cells? Trends Parasitol 2004;20:275-9. [PubMed: 15147678]

86. Tosoni A, Nebuloni M, Ferri A, et al. Disseminated microsporidiosis caused by Encephalitozoon cuniculi III (dog type) in an Italian AIDS patient: a retrospective study. Mod Pathol 2002;15:57783. [PubMed: 12011264]

87. Berg J, Diaz LE, Bender BS. Microsporidia in humans. Ann Intern Med 1996;125:522-3. [PubMed: 8779484]

88. Mertens RB, Didier ES, Fishbein MC, Bertucci DC, Rogers LB, Orenstein JM. Encephalitozoon cuniculi microsporidiosis: infection of the brain, heart, kidneys, trachea, adrenal glands, and urinary bladder in a patient with AIDS. Mod Pathol 1997;10:68-77. [PubMed: 9021729]

89. Molina JM, Oksenhendler E, Beauvais B, et al. Disseminated microsporidiosis due to Septata intestinalis in patients with AIDS: clinical features and response to albendazole therapy. J Infect Dis 1995;171:245-9. [PubMed: 7798674]

90. Lafaurie M, Sarfati C, Menotti J, Molina JM. Remission of disseminated infection caused by Encephalocytozoon intestinalis with highly active antiretroviral therapy. AIDS 2003;17:640-1. [PubMed: 12598791]

91. Cruz I, Morales MA, Noguer I, Rodriguez A, Alvar J. Leishmania in discarded syringes from intravenous drug users. Lancet 2002;359:1124-5. [PubMed: 11943264]

92. Leishmaniasis. Geneva: World Health Organization; 2005.

93. Desjeux P. Leishmaniasis: current situation and new perspectives. Comp Immunol Microbiol Infect Dis 2004;27:305-18. [PubMed: 15225981]

94. Alvar J, Canavate C, Gutierrez-Solar B, et al. Leishmania and human immunodeficiency virus coinfection: the first 10 years. Clin Microbiol Rev 1997;10:298-319. [PubMed: 9105756]

95. Olivier M, Badaro R, Medrano FJ, Moreno J. The pathogenesis of Leishmania/HIV coinfection: cellular and immunological mechanisms. Ann Trop Med Parasitol 2003;97(Suppl 1):79-98. [PubMed: 14678636]

96. Fernandez-Guerrero ML, Robles P, Rivas P, Mojer F, Muniz G, de Gorgolas M. Visceral leishmaniasis in immunocompromised patients with and without AIDS: a comparison of clinical features and prognosis. Acta Trop 2004;90:11-6. [PubMed: 14739017]

97. de La Rosa R, Pineda JA, Delgado J, et al. Incidence of and risk factors for symptomatic visceral leishmaniasis among human immunodeficiency virus type 1-infected patients from Spain in the era of highly active antiretroviral therapy. J Clin Microbiol 2002;40:762-7. [PubMed: 11880390]

98. Bernier R, Barbeau B, Tremblay MJ, Olivier M. The lipophosphoglycan of Leishmania donovani upregulates HIV-1 transcription in T cells through the nuclear factor-kappaB elements. J Immunol 1998;160:2881-8. [PubMed: 9510191]

99. Ferreira MS, Borges AS. Some aspects of protozoan infections in immunocompromised patients: a review. Mem Inst Oswaldo Cruz 2002;97:443-57. [PubMed: 12118272]

100. Frapier JM, Abraham B, Dereure J, Albat B. Fatal visceral leishmaniasis in a heart transplant recipient. J Heart Lung Transplant 2001;20:912-3. [PubMed: 11502416]

101. Gontijo CM, Pacheco RS, Orefice F, Lasmar E, Silva ES, Melo MN. Concurrent cutaneous, visceral and ocular leishmaniasis caused by Leishmania (Viannia) braziliensis in a kidney transplant patient. Mem Inst Oswaldo Cruz 2002;97:751-3. [PubMed: 12219147]

102. Hernandez-Perez J, Yebra-Bango M, Jimenez-Martinez E, et al. Visceral leishmaniasis (kala-azar) in solid organ transplantation: report of five cases and review. Clin Infect Dis 1999;29:918-21. [PubMed: 10589910]

103. Moroni G, Bossi L. Don't forget visceral leishmaniasis in transplant patients. Nephrol Dial Transplant 1995;10:563-4. [PubMed: 7624007]

104. Sirvent-von Bueltzingsloewen A, Marty P, Rosenthal E, et al. Visceral leishmaniasis: a new opportunistic infection in hematopoietic stem cell-transplanted patients. Bone Marrow Transplant 2004;33:667-8. [PubMed: 14730334]

105. Morales MA, Cruz I, Rubio JM, et al. Relapses versus reinfections in patients coinfected with Leishmania infantum and human immunodeficiency virus type 1. J Infect Dis 2002;185:1533-7. [PubMed: 11992294] 
106. Berenguer J, Gomez-Campdera F, Padilla B, et al. Visceral leishmaniasis (kala-azar) in transplant recipients: case report and review. Transplantation 1998;65:1401-4. [PubMed: 9625028]

107. Silveira FT, Lainson R, Corbett CE. Clinical and immunopathological spectrum of American cutaneous leishmaniasis with special reference to the disease in Amazonian Brazil: a review. Mem Inst Oswaldo Cruz 2004;99:239-51. [PubMed: 15273794]

108. Couppie P, Clyti E, Sobesky M, et al. Comparative study of cutaneous leishmaniasis in human immunodeficiency virus (HIV)-infected patients and non-HIV-infected patients in French Guiana. Br J Dermatol 2004;151:1165-71. [PubMed: 15606511]

109. Rosenthal E, Marty P, del Giudice P, et al. HIV and Leishmania coinfection: a review of 91 cases with focus on atypical locations of Leishmania. Clin Infect Dis 2000;31:1093-5. [PubMed: 11049794]

110. Kubar J, Marty P, Lelievre A, et al. Visceral leishmaniosis in HIV-positive patients: primary infection, reactivation and latent infection-impact of the CD4+ T-lymphocyte counts. AIDS 1998;12:2147-53. [PubMed: 9833855]

111. Albrecht H, Sobottka I, Emminger C, et al. Visceral leishmaniasis emerging as an important opportunistic infection in HIV-infected persons living in areas nonendemic for Leishmania donovani. Arch Pathol Lab Med 1996;120:189-98. [PubMed: 8712898]

112. Asensi V, Tricas L, Meana A, et al. Visceral leishmaniasis and other severe infections in an adult patient with p47-phox-deficient chronic granulomatous disease. Infection 2000;28:171-4. [PubMed: 10879644]

113. Hashim FA, Ahmed AE, el Hassan M, et al. Neurologic changes in visceral leishmaniasis. Am J Trop Med Hyg 1995;52:149-54. [PubMed: 7872442]

114. Karak B, Garg RK, Misra S, Sharma AM. Neurological manifestations in a patient with visceral leishmaniasis. Postgrad Med J 1998;74:423-5. [PubMed: 9799919]

115. Chunge CN, Gachihi G, Muigai R. Is neurological involvement possible in visceral leishmaniasis in Kenya. Trans R Soc Trop Med Hyg 1985;79:872. [PubMed: 3832498]

116. Mustafa D. Neurological disturbances in visceral leishmaniasis. J Trop Med Hyg 1965;68:248-50. [PubMed: 4284534]

117. Huna-Baron R, Warren FA, Miller W, Jacobs J, Green J, Kupersmith MJ. Mucosal leishmaniasis presenting as sinusitis and optic neuropathy. Arch Ophthalmol 2000;118:852-4. [PubMed: 10865330]

118. Fasanaro AM, Scoleri G, Pizza V, Gaeta GB, Fasanaro A. Guillain-Barré syndrome as presenting manifestation of visceral leishmaniasis. Lancet 1991;338:1142. [PubMed: 1682557]

119. Attarian S, Serratrice J, Mazodier C, Disdier P, Azulay JP, Pouget J. Guillain-Barré syndrome revealing visceral leishmaniasis in an immunocompetent woman [in French]. Rev Neurol (Paris) 2003;159:1046-8. [PubMed: 14710025]

120. Medrano FJ, Hernandez-Quero J, Jimenez E, et al. Visceral leishmaniasis in HIV-1-infected individuals: a common opportunistic infection in Spain? AIDS 1992;6:1499-503. [PubMed: 1362880]

121. Piarroux R, Gambarelli F, Dumon H, et al. Comparison of PCR with direct examination of bone marrow aspiration, myeloculture, and serology for diagnosis of visceral leishmaniasis in immunocompromised patients. J Clin Microbiol 1994;32:746-9. [PubMed: 8195388]

122. Prasad LS, Sen S. Migration of Leishmania donovani amastigotes in the cerebrospinal fluid. Am J Trop Med Hyg 1996;55:652-4. [PubMed: 9025693]

123. Dereure J, Pratlong F, Reynes J, Basset D, Bastien P, Dedet JP. Haemoculture as a tool for diagnosing visceral leishmaniasis in HIV-negative and HIV-positive patients: interest for parasite identification. Bull World Health Organ 1998;76:203-6. [PubMed: 9648362]

124. Bretagne S, Durand R, Olivi M, et al. Real-time PCR as a new tool for quantifying Leishmania infantum in liver in infected mice. Clin Diagn Lab Immunol 2001;8:828-31. [PubMed: 11427436]

125. Singh S, Sivakumar R. Challenges and new discoveries in the treatment of leishmaniasis. J Infect Chemother 2004;10:307-15. [PubMed: 15614453]

126. Laguna F. Treatment of leishmaniasis in HIV-positive patients. Ann Trop Med Parasitol 2003;97 (Suppl 1):135-42. [PubMed: 14678640] 
127. Lopez-Velez R, Perez-Molina JA, Guerrero A, et al. Clinicoepidemiologic characteristics, prognostic factors, and survival analysis of patients coinfected with human immunodeficiency virus and Leishmania in an area of Madrid, Spain. Am J Trop Med Hyg 1998;58:436-43. [PubMed: 9574788]

128. Calza L, Marinacci G, Manfredi R, Colangeli V, Fortunato L, Chiodo F. Pentamidine isethionate as treatment and secondary prophylaxis for disseminated cutaneous leishmaniasis during HIV infection: case report. J Chemother 2001;13:653-7. [PubMed: 11806628]

129. Thakur CP, Sinha GP, Pandey AK, Barat D, Sinha PK. Amphotericin B in resistant kala-azar in Bihar. Natl Med J India 1993;6:57-60. [PubMed: 8477209]

130. Kuzoe FA. Current situation of African trypanosomiasis. Acta Trop 1993;54:153-62. [PubMed: 7902654]

131. Kennedy PG. Human African trypanosomiasis of the CNS: current issues and challenges. J Clin Invest 2004;113:496-504. [PubMed: 14966556]

132. Noireau F, Brun-Vezinet F, Larouze B, Nzoukoudi MY, Gouteux JP. Absence of relationship between human immunodeficiency virus 1 and sleeping sickness. Trans R Soc Trop Med Hyg 1987;81:1000. [PubMed: 3503396]

133. Meda HA, Doua F, Laveissiere C, et al. Human immunodeficiency virus infection and human African trypanosomiasis: a case-control study in Cote d'Ivoire. Trans R Soc Trop Med Hyg 1995;89:639_ 43. [PubMed: 8594681]

134. Louis JP, Moulia-Pelat JP, Jannin J, et al. Absence of epidemiological inter-relations between HIV infection and African human trypanosomiasis in central Africa. Trop Med Parasitol 1991;42:155. [PubMed: 1896776]

135. Chretien JP, Smoak BL. African trypanosomiasis: changing epidemiology and consequences. Curr Infect Dis Rep 2005;7:54-60. [PubMed: 15610672]

136. Apted, F. Clinical manifestations and diagnosis of sleeping sickness. In: Mulligan, HW., editor. The African trypanosomasis. London: Allen and Unwin; 1970. p. 661-83.

137. de Atouguia, J.; Kennedy, PGE. Neurological aspects of human African trypanosomiasis. In: Davis, LE.; Kennedy, PGE., editors. Infectious diseases of the nervous system. Oxford: ButterworthHeinemann; 2000. p. 321-72.

138. Burri C, Nkunku S, Merolle A, Smith T, Blum J, Brun R. Efficacy of new, concise schedule for melarsoprol in treatment of sleeping sickness caused by Trypanosoma brucei gambiense: a randomised trial. Lancet 2000;355:1419-25. [PubMed: 10791526]

139. Buguet A, Bisser S, Josenando T, Chapotot F, Cespuglio R. Sleep structure: a new diagnostic tool for stage determination in sleeping sickness. Acta Trop 2005;93:107-17. [PubMed: 15589803]

140. World Health Organization. Control and surveillance of African trypanosomiasis. World Health Organ Tech Rep Ser 1998;881:1-113.

141. Lejon V, Reiber H, Legros D, et al. Intrathecal immune response pattern for improved diagnosis of central nervous system involvement in trypanosomiasis. J Infect Dis 2003;187:1475-83. [PubMed: 12717630]

142. Gill DS, Chatha DS, del Carpio-O'Donovan R. MR imaging findings in African trypansomiasis. AJNR Am J Neuroradiol 2003;24:1383-5. [PubMed: 12917133]

143. Nok AJ. Arsenicals (melarsoprol), pentamidine and suramin in the treatment of human African trypanosomiasis. Parasitol Res 2003;90:71-9. [PubMed: 12743807]

144. Schmid C, Nkunku S, Merolle A, Vounatsou P, Burri C. Efficacy of 10-day melarsoprol schedule 2 years after treatment for late-stage gambiense sleeping sickness. Lancet 2004;364:789-90. [PubMed: 15337407]

145. Abel PM, Kiala G, Loa V, et al. Retaking sleeping sickness control in Angola. Trop Med Int Health 2004;9:141-8. [PubMed: 14728618]

146. Blum J, Nkunku S, Burri C. Clinical description of encephalopathic syndromes and risk factors for their occurrence and outcome during melarsoprol treatment of human African trypanosomiasis. Trop Med Int Health 2001;6:390-400. [PubMed: 11348533]

147. Pepin J, Ethier L, Kazadi C, Milord F, Ryder R. The impact of human immunodeficiency virus infection on the epidemiology and treatment of Trypanosoma brucei gambiense sleeping sickness in Nioki, Zaire. Am J Trop Med Hyg 1992;47:133-40. [PubMed: 1503182] 
148. De Clercq E. Suramin: a potent inhibitor of reverse transcriptase of RNA tumor viruses. Cancer Lett 1979;8:9-22. [PubMed: 92362]

149. Dedet JP, Pratlong F. Leishmania, Trypanosoma and monoxenous trypanosomatids as emerging opportunistic agents. J Eukaryot Microbiol 2000;47:37-9. [PubMed: 10651294]

150. Morales P, Torres JJ, Salavert M, Peman J, Lacruz J, Sole A. Visceral leishmaniasis in lung transplantation. Transplant Proc 2003;35:2001-3. [PubMed: 12962876]

151. Vithayasai P, Vithayasai V. Clinical manifestations of 174 AIDS cases in Maharaj Nakorn Chiang Mai Hospital. J Dermatol 1993;20:389-93. [PubMed: 8408918]

152. Cecchini A, Pricca P, Mariani P, et al. Neuro-AIDS: a multicenter neuroradiological study [in Italian]. Radiol Med (Torino) 1989;77:602-12. [PubMed: 2756176]

153. Berger BJ, Fairlamb AH. Interactions between immunity and chemotherapy in the treatment of the trypanosomiases and leishmaniases. Parasitology 1992;105(Suppl):S71-8. [PubMed: 1308932]

154. Bonnet F, Morlat P, Chene G, et al. Causes of death among HIV-infected patients in the era of highly active antiretroviral therapy, Bordeaux, France, 1998-1999. HIV Med 2002;3:195-9. [PubMed: 12139658]

155. Dupouy-Camet J. New drugs for the treatment of human parasitic protozoa [in French]. Parassitologia 2004;46:81-4. [PubMed: 15305692]

156. Figueiro-Filho EA, Duarte G, El-Beitune P, Quintana SM, Maia TL. Visceral leishmaniasis (kalaazar) and pregnancy. Infect Dis Obstet Gynecol 2004;12:31-40. [PubMed: 15460194] 
Table 1

Transplant type and risk of parasitic infection.

\begin{tabular}{|c|c|c|}
\hline Transplant & Disease & Comments \\
\hline Heart & Leishmaniasis & Only 2 cases are reported in the literature \\
\hline Lung & Leishmaniasis, microsporidiasis & $\begin{array}{l}\text { Reported in persons living in or traveling to } \\
\text { Mediterranean countries }\end{array}$ \\
\hline Liver & Microsporidiasis & More common in pediatric transplant patients \\
\hline Kidney and/or pancreas & Leishmaniasis, microsporidiasis, malaria & $\begin{array}{l}\text { Disseminated leishmaniasis tends to occur between 6- } \\
12 \text { months after transplantation; concurrent } \\
\text { cytomegalovirus dissemination may be seen with } \\
\text { microsporidial infection in renal transplantation; } \\
\text { malaria has been transmitted via renal transplantation }\end{array}$ \\
\hline Bone marrow & Leishmaniasis, microsporidiasis, malaria & $\begin{array}{l}\text { Only reported in animal studies; malaria reported } \\
\text { following receipt of a transplant from an infected donor }\end{array}$ \\
\hline
\end{tabular}

NOTE. Adapted from [29,30,71-74,96,106,149,150]. 
Table 2

Neurologic and neuroimaging findings associated with selected parasitic CNS infections.

\begin{tabular}{|c|c|c|c|}
\hline Disease & Neurologic manifestations & Neuroimaging findings & Comments \\
\hline Malaria & $\begin{array}{l}\text { Coma, seizures, cranial nerve } \\
\text { dysfunction, cognitive dysfunction; } \\
\text { neurologic syndrome after malaria }\end{array}$ & $\begin{array}{l}\text { Cerebral edema, multifocal } \\
\text { cortical or subcortical lesions that } \\
\text { may be enhanced after } \\
\text { gadolinium administration, high } \\
\text { signal intensity on diffusion- } \\
\text { weighted imaging and decreased } \\
\text { signal on apparent diffusion } \\
\text { coefficient maps }\end{array}$ & $\begin{array}{l}\text { Severe malaria is more common } \\
\text { among HIV-infected people than } \\
\text { others }\end{array}$ \\
\hline Trypanosomiasis & $\begin{array}{l}\text { Mental status changes and sleep, } \\
\text { motor, and speech disturbances }\end{array}$ & $\begin{array}{l}\text { Hypointensity of the basal } \\
\text { ganglia }\end{array}$ & $\begin{array}{l}\text { HIV-infected people have higher } \\
\text { risk for treatment failure and } \\
\text { worse outcome of both HAT and } \\
\text { HIV; no posttransplantation cases } \\
\text { have been reported }\end{array}$ \\
\hline Microsporidiasis & $\begin{array}{l}\text { Multifocal deficits; seizures are } \\
\text { common }\end{array}$ & $\begin{array}{l}\text { Multiple ring enhancing lesions } \\
\text { that can involve grey and white } \\
\text { matter }\end{array}$ & $\begin{array}{l}\text { CNS infection occurs only during } \\
\text { disseminated infection; in HIV- } \\
\text { infected people, it is often } \\
\text { accompanied by microsporidial } \\
\text { sinusitis or keratoconjunctivitis }\end{array}$ \\
\hline Leishmaniasis & $\begin{array}{l}\text { Peripheral neuropathy, cranial } \\
\text { nerve dysfunction, meningitis, } \\
\text { optic nerve involvement, Guillain- } \\
\text { Barre syndrome }\end{array}$ & Usually normal & $\begin{array}{l}\text { CNS manifestations are } \\
\text { uncommon regardless of host } \\
\text { immune status; the most common } \\
\text { neurologic manifestation of } \\
\text { leishmaniasis is peripheral } \\
\text { neuropathy }\end{array}$ \\
\hline
\end{tabular}

NOTE. Adapted from [77,112-117,119,137,142,151,152]. HAT, human African trypanosomiasis. 
Table 3

Diagnostic testing for selected parasitic CNS infections.

\begin{tabular}{|c|c|c|c|c|}
\hline Variable & Malaria & Trypanosomiasis & Microsporidiasis & Leishmaniasis \\
\hline \multicolumn{5}{|l|}{ Specimen } \\
\hline Serum & $\begin{array}{l}\text { Serological tests } \\
\text { (ParaSight-F and } \\
\text { Immunochromoto- } \\
\text { graphic Malaria } \\
\text { Plasmodium } \\
\text { falciparum test) are } \\
\text { available, but false } \\
\text { positive tests are } \\
\text { common }\end{array}$ & $\ldots$ & $\begin{array}{l}\text { Spores are seen in serum } \\
\text { samples only during } \\
\text { massive dissemination }\end{array}$ & $\begin{array}{l}\text { ELISA and } \\
\text { immunofluorescence } \\
\text { assay have low } \\
\text { sensitivity, compared } \\
\text { with PCR }\end{array}$ \\
\hline $\mathrm{CSF}$ & $\ldots$ & $\begin{array}{l}\text { WBC count } 15 \text { cells/ } \\
\mu \mathrm{L} \text { and organisms } \\
\text { detected; CSF } \\
\text { trypanosomal IgM } \\
\text { may be helpful in } \\
\text { early stages of disease }\end{array}$ & $\begin{array}{l}\text { Spores can rarely be } \\
\text { detected }\end{array}$ & $\ldots$ \\
\hline Stool & $\ldots$ & $\ldots$ & $\begin{array}{l}\text { Light microscopy of } \\
\text { fecal samples to identify } \\
\text { spores }\end{array}$ & $\ldots$ \\
\hline Urine & $\ldots$ & $\ldots$ & $\begin{array}{l}\text { Asymptomatic } \\
\text { shedding can be } \\
\text { detected in urinary } \\
\text { sediment up to } 6 \text { months } \\
\text { before renal failure or } \\
\text { dissemination ensues }\end{array}$ & $\ldots$ \\
\hline Skin scraping & $\ldots$ & $\ldots$ & $\ldots$ & In cutaneous form \\
\hline $\begin{array}{l}\text { Gold standard for } \\
\text { diagnosis }\end{array}$ & $\begin{array}{l}\text { Detection of parasites } \\
\text { on thick and thin blood } \\
\text { smears with Giemsa } \\
\text { staining }\end{array}$ & $\begin{array}{l}\text { Detection of } \\
\text { organisms in CSF } \\
\text { samples; card } \\
\text { aggglutination } \\
\text { trypanosomiasis test }\end{array}$ & $\begin{array}{l}\text { Transmission electron } \\
\text { microscopy may be } \\
\text { useful for identification } \\
\text { of species, but light } \\
\text { microscopy is adequate } \\
\text { for diagnosis }\end{array}$ & $\begin{array}{l}\text { Culture of a biopsy } \\
\text { specimen is required for } \\
\text { speciation }\end{array}$ \\
\hline
\end{tabular}

NOTE. Adapted from [47,78,79,107,121,124,141]. 
Table 4

Treatment of selected parasitic CNS infections.

\begin{tabular}{|c|c|c|c|}
\hline Disease & Treatment & Suppressive therapy required & Comments \\
\hline Malaria & $\begin{array}{l}\text { For suspected cerebral malaria } \\
\text { due to Plasmodium species } \\
\text { with chloroquine resistance or } \\
\text { unknown resistance, treatment } \\
\text { should include a } 10-\mathrm{mg} / \mathrm{kg} \text { iv } \\
\text { loading dose of quinidine in } \\
\text { normal saline for } 1-2 \mathrm{~h} \text {; then } \\
0.02 \mathrm{mg} / \mathrm{kg} \text { iv per min of } \\
\text { quinidine until patient can } \\
\text { swallow; then quinine tablets, } \\
\text { administered at } 30 \mathrm{mg} / \mathrm{kg} \\
\text { for } 3-7 \text { days }{ }^{a}\end{array}$ & No & $\begin{array}{l}\text { Use of steroids and } \\
\text { prophylactic } \\
\text { anticonvulsants in } \\
\text { patients with cerebral } \\
\text { malaria have been } \\
\text { associated with } \\
\text { worse outcome; } \\
\text { elevated intracranial } \\
\text { pressure should be } \\
\text { treated with mannitol }\end{array}$ \\
\hline Microsporidiosis & Albendazole $400 \mathrm{mg}$ b.i.d. & Unknown & $\begin{array}{l}\text { HAART therapy for } \\
\text { HIV-positive } \\
\text { patients }\end{array}$ \\
\hline Trypanosoma rhodesiense infection & $\begin{array}{l}\text { Melarsoprol } 2-3.6 \mathrm{mg} / \mathrm{kg} \text { per } \\
\text { day for } 3 \text { days; after } 7 \text { days, } 3.6 \\
\mathrm{mg} / \mathrm{kg} \text { per day for } 3 \text { days; } \\
\text { repeat after } 7 \text { days }\end{array}$ & No & $\begin{array}{l}\text { Early stage: } \\
\text { intravenous suramin } \\
100-200 \mathrm{mg} \text { (test } \\
\text { dose), then } 1 \mathrm{~g} \text { iv } \\
\text { administered on days } \\
1,3,7,14 \text {, and } 21\end{array}$ \\
\hline Trypanosoma gambiense infection & $\begin{array}{l}\text { Eflornithine } 100 \mathrm{mg} / \mathrm{kg} \text { q.i.d. } \\
\text { for } 2 \text { weeks or melarsoprol } 2.2 \\
\mathrm{mg} / \mathrm{kg} \text { q.d. for } 10 \text { days }\end{array}$ & No & $\begin{array}{l}\text { Early stage: } \\
\text { pentamidine } 4 \mathrm{mg} / \mathrm{kg} \\
\text { im per day for } 10 \\
\text { days or suramin } 100- \\
200 \mathrm{mg} \text { (test dose) iv, } \\
\text { then } 1 \mathrm{~g} \text { iv } \\
\text { administered on days } \\
1,3,7,14 \text {, and } 21\end{array}$ \\
\hline Leishmaniasis & $\begin{array}{l}\text { Sodium stibogluconate } 20 \mathrm{mg} / \\
\mathrm{kg} \text { iv or im per day for } 28 \mathrm{days} \\
\text { or amphotericin B } 0.5-1 \mathrm{mg} / \\
\mathrm{kg} \text { iv daily or every second day } \\
\text { for up to } 8 \text { weeks or liposomal } \\
\text { amphotericin B } 3 \mathrm{mg} / \mathrm{kg} \text { iv per } \\
\text { day (days } 1-5 \text { ) and } 3 \mathrm{mg} / \mathrm{kg} \text { iv } \\
\text { per day (days } 14 \mathrm{and} 21 \text { ) or } \\
\text { pentamidine } 4 \mathrm{mg} / \mathrm{kg} \text { iv or im } \\
\text { daily or every second day for } \\
15-30 \text { doses }\end{array}$ & Yes & $\begin{array}{l}\text { Amphotericin B is } \\
\text { recommended for } \\
\text { HIV-infected people } \\
\text { and pregnant women }\end{array}$ \\
\hline
\end{tabular}

NOTE. Adapted from [6,37,38,48,55,57,77,105,108,144,145,149,153-156].

${ }^{a}$ For additional options, see [6]. 